Jurnal Ners Volume 2 Nomor 1 Tahun 2018 Halaman 72 - 85

JURNAL NERS

Research \& Learning in Nursing Science

http://journal.universitaspahlawan.ac.id/index.php/ners

\title{
HUBUNGAN RESPONSE TIME PELAYANAN INSTALASI GAWAT DARURAT (IGD) DENGAN TINGKAT KEPUASAN PASIEN DI RSUD BANGKINANG TAHUN 2018
}

\author{
Gusman Virgo \\ Dosen Program Studi Sarjana Keperawatan \\ Universitas Pahlawan Tuanku Tambusai \\ gusmanvirgo@gmail.com
}

\begin{abstract}
Abstrak
Salah satu indikator keberhasilan penanggulangan medik penderita gawat darurat adalah kecepatan memberikan pertolongan yang memadai kepada penderita gawat darurat baik pada keadaan rutin sehari-hari atau sewaktu bencana. Keberhasilan waktu tanggap atau response time sangat tergantung kepada kecepatan yang tersedia serta kualitas pemberian pertolongan untuk menyelamatkan nyawa pasien. Tujuan penelitian ini adalah untuk mengetahui hubungan response time pelayanan Instalasi Gawat Darurat (IGD) dengan tingkat kepuasan pasien di RSUD Bangkinang tahun 2018. Jenis penelitian analitik dengan rancangan cros sectional. Populasi dalam penelitian ini adalah pasien yang datang ke IGD dengan jumlah 80 orang yang diambil dengan teknik accidental sampling.alat pengumpulan data yang digunakan adalah kuesioner. Analisa data menggunakan analisa univariat dan bivariat.Dari hasil penelitian didapatkan bahwa sebagian besar respon time perawat IGD adalah lambat ( $\geq 5$ menit) yaitu 51 orang $(63,8 \%)$, sebagian besar pasien tidak puas dengan pelayanan IGD yaitu 47 orang $(58,8 \%$. Berdasarkan uji statistik ada hubungan Response Time Pelayanan Instalasi Gawat Darurat (IGD) Dengan Tingkat Kepuasan Pasien di RSUD Bangkinang tahun 2018 dengan $\mathrm{p}$ value 0,002. Diharapkan diharapkan kepada perawat agar menerapkan respon time pada pasien dengan cepat terhadap kegawatdaruratan di Instalasi Gawat Darurat.
\end{abstract}

\section{Kata Kunci : Respon Time, Kepuasan pasien}

$\triangle$ Corresponding author :

Address : Jl. Tuanku Tambusai No. 23 Bangkinang

Email : gusmanvirgo@gmail.com

Phone : 085278005288 


\section{BAB 1}

\section{PENDAHULUAN}

\section{A. Latar Belakang}

Pelayanan kesehatan mengalami perkembangan dalam upaya menghadapi era globalisasi yang menuntut persaingan yang cukup tinggi di antara rumah sakit baik rumah sakit swasta maupun pemerintah. Pada kondisi persaingan yang tinggi, pelanggan memiliki informasi yang memadai dan mampu untuk memilih diantara beberapa alternatif pelayanan yang ada. Oleh karena itu untuk memenangkan persaingan dalam mendapatkan pelanggan, rumah sakit harus dapat memberikan pelayanan kesehatan yang berkualitas yang dapat memberikan kepuasan pada pasien dan keluarga (Basuki, 2015).

Rumah sakit merupakan suatu instansi atatu organisasi yang harus mempunyai manajeman yang baik guna memberikan pelayanan terhadap pasien. Salah satu bagian terpenting dari rumah sakit adalah Instalasi Gawat Darurat (IGD). IGD merupakan pintu utama untuk masuknya semua pasien baik dengan kondisi emergency. IGD adalah salah satu bagian rumah sakit yang melakukan tindakan berdasarkan triage keadaan pasien (Musliha, 2010). Pembagian triage pada pasien sangat penting guna mencegah kecatatan dan kematian pada pasien. Oleh sebab iti petugas IGD khususnya dokter dan perawat harus mempunyai kecepatan, keterampilan dan kesiagaan yang lebih dari petugas medis di ruangan lain (Samsinar, 2014).

Standar keperawatan di rumah sakit diharapkan dapat digunakan untuk menetapkan kualifikasi dan jenis pelayanan di rumah sakit. Filasofi penanganan gawat darurat yaitu Times Saving Life Saving, artinya setiap tindakan yang dilakukan guna menolong pasien haruslah efektif dan efisien. Henti nafas selama 2-3 menit dapat mengakibatkan kematian yang akan berlanjut ke kematian jaringan (Sartoto, 2010).
Instalasi gawat sarurat merupakan salah satu unit pelayanan di rumah sakit yang memberikan pertolonagn pertama dan sebagai jalan utama masuknya pasien dengan kondisi gawat dadurat. Keadaan gawat darurat adalah suatu keadaan klinis dimana pasien membutuhkan pertolongan medis yang cepat untuk menyelamatkan nyawa dan kecatatan lebih lanjut (Depkes RI, 2012).

Salah satu indicator keberhasilan penanggulangan medic penderita gawat darurat adalah kecepatan memberikan pertolongan yang memadai kepada penderita gawat darurat baik pada keadaaan rutin sehari-hari maupun sewaktu bencana. Keberhasilan waktu tanggap sangat tergantung pada kecepatan yang tersedia serta kualitas pemberian pertolongan untuk menyelamatkan nyawa atau mencegah catat sejak di tempat kejadian dalam perjalanan hingga pertolongan rumah sakit, pertama sakit dan fase rumah sakit. Kedua komponen tersebut sama pentingnya dalam upaya pertolongan gawat darurat (Muwardi, 2015).

Respon time perawat merupakan gabungan dari waktu tunggu atau waktu respon saat pasien tiba di depan pintu rumah sakit sampai mendapatkan tanggapan atau respon dari petugas melalui gawat darurat dengan waktu pelayanan yaitu waktu yang diperlukan pasien sampai selesai (Haryatun, 2008).

Kecepatan dan ketepatan pertolongan yang diberikan pada pasien Instalansi Gawat Darurat harus sesuai dengan kompetensi dan standar pelayanan sehingga penanganan yang diberikan berdasarkan respon time yang cepat dan tindakan yang cepat. Ketepatan waktu dalam pelayanan kegawatdaruratan menjadi perhatian penting di Negara-negara seluruh dunia. Hasil studi dati Nationak Health Service (NHS) di Inggris, Australia, Amerika dan Kanada bahwa pelayanan keperawatan di Instalasi Gawat Darurat mempengaruhi tingkat kepuasan pasien (Suhartati, 2011). 
Data kunjungan masuk ke IGD Indonesia sebanyak 4.402.205 pasien. Pelayanan gawat darurat di Provinsi Riau mengalami peningkatan pada tahun 20152016 dari $98,80 \%$ menjadi $100 \%$ dengan berbagai keluhan pasien yang berkunjung (Widyawati, 2016).

Rumah Sakit Umum Daerah Bangkinang adalah salah satu rumah sakit yang berada di Kabupaten Kampar yang memberikan pelayanan IGD selamma 24 jam. Berdasarkan data respon tme yang didapatkan dari RSUD Bangkinang dari bulan Desember 2017 sampai bulan maret 2018 tercatat respon time IGD dengan waktu penanganan lebih dari lima menit adalah 282 kasus.

Berdasarkan studi pendahuluan kunjungan pasien IGD Bangkinang tahun 2017 dapat dilihat pada tabel berikut:

Tabel 1.1 Data Kunjungan IGD di RSUD Bangkinang tahun 2018

\begin{tabular}{|c|c|c|}
\hline No & Bulan & Jumlah \\
\hline 1. & Januari & 1126 \\
\hline 2. & Februari & 1079 \\
\hline 3. & Maret & 1138 \\
\hline & Jumlah & 3.343 \\
\hline
\end{tabular}

Berdasarkan tabel 1.1 dapat dilihhat bahwa jumlah pasien IGD di RSUD Bangkinang mencapai 3.343 pasien. Hasil kritik dan saran bulan Mei yang diberikan kepada 40 pasien, pasin mengatakan $40 \%$ puas terhadap pelayanan yang diberikan oleh petugas medis dan $60 \%$ pasien mengatakan tidak puas dan memberikan kritik saran kepada petugas medis untuk lebih cepat dan sigap dalam melayani pasien.

Jumlah dan kualifikasi tenaga dokter dan perawat IGD harian memenuhi syarat sesuai dengan kebutuhan pasien. Petugas kesehatan IGD terdiri dari Ka. Instalasi IGD 1 orang, kepala ruangan 1 orang, dokter umum fuul time 5 ornag, perawat yang memenuhi sertifikasi BTCLS berjumlah 14 orang, STR berjumlah 15 orang dan SIP berjumlah 15 orang.

Perawat pelaksana terdiri dari 14 orang. Berdasarkan perhitungan pola ketenagakerjaan RSUD Bangkinang tahun 2017, perawat yang dibutuhkan IGD adala 29 orang. Perhitungan ini berdasarkan jumlah kunjungan pasien rata-rata 40 pasien per hari dan jumlah jam kerja perawat dan jumlah hari efektif dalam setahun yaitu 285 hari. Berdasarkan jumlah standar ketenagaan tersebut, IGD belum sesuai dengan ketenagaan rumah sakit, karena IGD hanya mempunyai tenaga keperawatan berjumlah 14 orang,

sedangkan standar ketenagaan adalah 29 orang (RSUD, 2017).

Setiap melakukan tindakan di RSUD Bangkinang sesuai dengan SOP, trige di IGD dan sudah sesuai dengan standar pelayanan yaitu mendahulukan pasien pada triase hijau. Pasien ditangani bukan berdasarkan urutan kedatangganm tatapi berdasarkan kegawatan, kepuasan pasien terhadap pelayanan IGD pada setiap triase berbeda-beda, pasien ingin segera mendapat penangana media dan ingin didahulukan.

Pada dasarnya pasien ingin mendapatkan pelayanan yang sebaik-baiknya pada pelayanan jasa yang mereka pilih. Kepuasan pasien adalah salah satu indicator kualitas pelayanan yang kita berikan. Pasien baru akan merasa puas apabila kinerja perawat yang diperolehnya sama atau melebihi daripada yang diharapkan dan sebaliknya., ketidakpuasan akan timbul atau perasaan kecewa pasien akan terjadi apabila kinerja perawat diperolehnya tidak sesuai dengan harapannya (Bustami, 2011).

Kepuasan dimulai dar penerimaan pertama pasien datang sampai mendapatkan penanganan, pelayanan dibentuk 
berdasarkan 5 prinsip service quality yaitu kecepatan, ketepatan, keamanan, keramahan.

Berdasarkan survey awal yang peneliti lakukan terhadap 10 perawat di IGD, didapatkan 6 orang $(60 \%)$ respon time di IGD dengan waktu penanganan lebih dari 5 menit dan hanya 4 orang $(40 \%)$ perawat dengan respon time kurang dari 5 menit. Sedangkan dari wawancara terhadap 10 orang keluarga pasien yang dirawat, 6 orang mengatakan tidak puas terhadap pelayanan IGD dan hanya 4 orang yang puas terhadap pelayanan IGD.

Berdasarkan latar belakang diatas, msks peneliti tertarik untuk melakukan penelitian dengan judul " Hubungan Respon Time pelayanan Instalasi Gawat Darurat (IGD) dengan Tingkat Kepuasan Pasien di RSUD Bangkinang tahun 2018.

\section{B. Rumusan Masalah}

Rumusan masalah dalam penelitian ini adalah " Adakah Hubungan Respon Time pelayanan Instalasi Gawat Darurat (IGD) dengan Tingkat Kepuasan Pasien di RSUD Bangkinang tahun 2018"?

\section{Tujuan Penelitian}

1. Tujuan Umum: Untuk Mengetahui hubungan respon time pelayanan Instalasi Gawat Darurat (IGD) dengan Tingkat Kepuasan Pasien di RSUD Bangkinang tahun 2018.

2. Tujuan Khusus"

a. Untuk mengetahui gambaran respon time di IGD RSUD Bangkinang tahun 2018

b. Untuk mengetahui gambaran kepuasan di IGD RSUD Bangkinang tahun 2018

c. Untuk mengetahui hubungan respon time pelayanan Instalasi Gawat Darurat (IGD) dengan Tingkat Kepuasan Pasien di RSUD Bangkinang tahun 2018

\section{Manfaat Penelitian}

Penellitian ini diharapkan dapat memberikan manfaat bagi:

1. Instansi Terkait yaitu RSUD Bangkinang memberikan sumbangan bagi perkembangan usaha jasa agar memberikan pelayanan yang sesuai dengan standar operasional dan meningkatkan kualitas pelayanan dan juga sebagai bahan pertimbangan RSUD

2. Bangkinang dalam meningkatkan kualitas pelayanan yang sesuai dengan standar operasional.

3. Hasil penelitian ini diharapkan dapat menjadi acuan untuk perawat dalam pelaksanaan pelayanan gawat darurat secara cepat dan sesuai dengan kompetensi perawat sebagai penurunana angka kesakitan, kecatatan dan komplikasi

4. Bagi Penelitian Selanjutnya

Penelitian ini diharapkan dapat menambah informasi baru bagi ilmu pengetahuan guna menambah pengetahuan dan wawasan tentang respon time perawat dalam penanganan kegawat daruratan, penelitian ini juga diharapkan dapat dijadikan bagi peneliti selanjutnya yang ingin meneliti tentang efektifitas perawat IGS

5. Bagi Pasien

Penelitian ini diharapkan dapat bermanfaat bagi pasien dan keluarga dengan mengetahui tentang waktu tunggu yang diberikan oleh seorang petugas diruang IGD membuat keluarga tidak cemas, lebih percaya diri terhadap petugas IGD dan tidak terdapat kesalah pahaman terhadap pelayanan yang diberikan.

\section{BAB III METODE PENELITIAN}

\section{A. Desain Penelitian}

Desain penelitian ini adalah analitik dengan rancangan cross sectional (potong lintang), yaitu setiap variabel diobservasi hanya satu kali saja dan pengukuran masing-masing variabel dilakukan pada waktu yang sama (Notoatmodjo, 2010). Adapaun rancangan penelitian dapat dilihat pada skema 3.1 berikut ini : 
1. Rancangan Penelitian

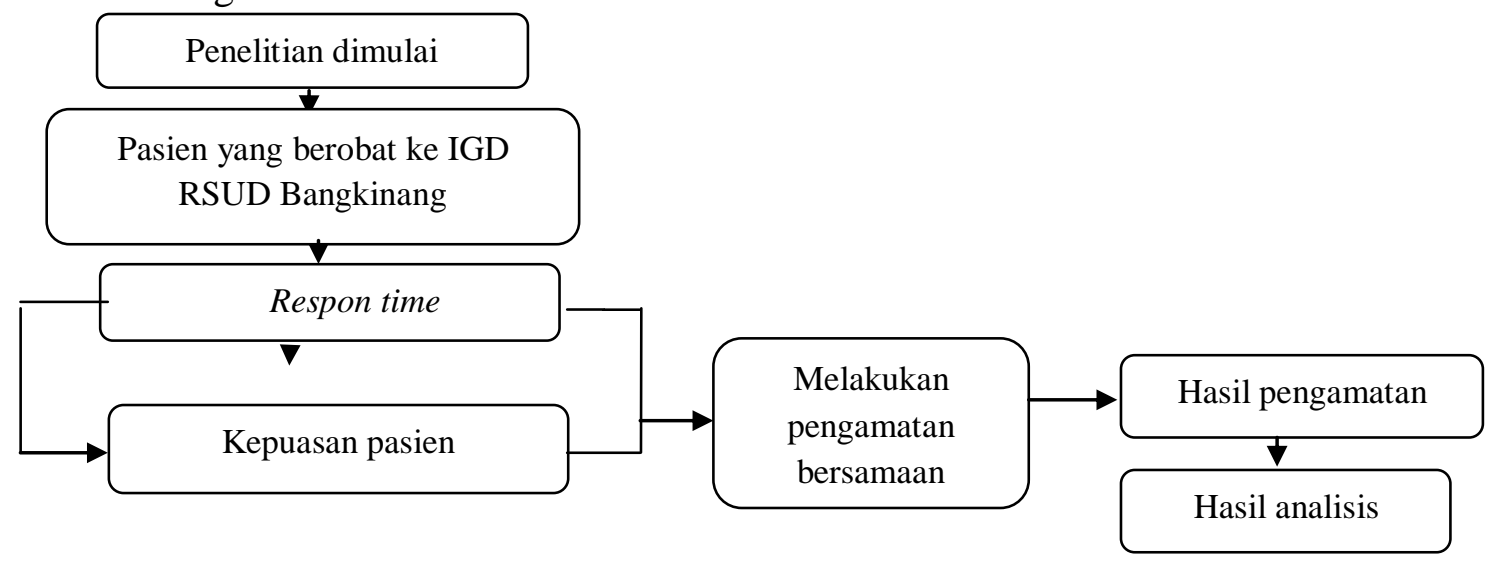

Skema 3.1. Rancangan Penelitian (Notoatmodjo, 2010)

\section{Alur Penelitian}

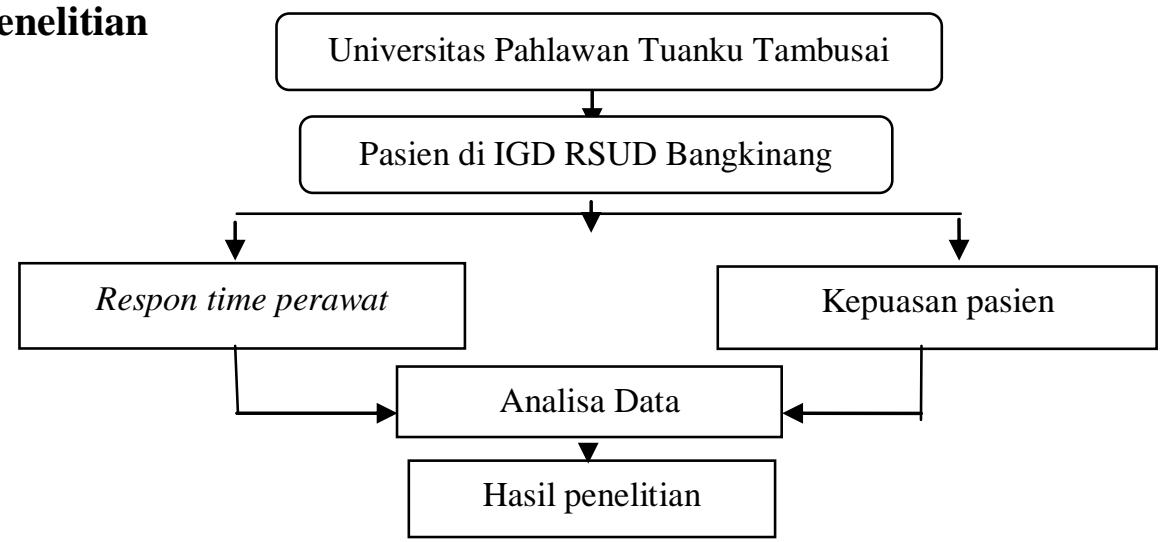

\section{Skema 3.2 Alur Penelitian}

\section{ProsedurPenelitian}

Adapun prosedur dalam penelitian ini adalah:
a. Mengajukan surat permohonan izin
pengambilan data di RSUD Bangkinang.
b. Setelah data didapatkan menentukan tempat penelitian.
c. Mengajukan surat izin pengambilan data ke RSUD Bangkinang
d. Melakukan seminar proposal.
e. Melakukan penelitian
f. Melakukan pengolahan data
g. Melakukan seminar hasil.

\section{Variable Dalam Penelitian}

Variabel - variabel yang diteliti pada penelitian ini adalah : a. Variabel Bebas (Independent Variable)

Variabel ini sering disebut sebagai variabel stimulus, input, prediktor dan antecendent. Variabel bebas adalah variabel yang menjadi sebab timbulnya atau berubahnya variabel dependen. Sedangkan variabel bebas dalam penelitian ini adalah respon time perawat

b. Variabel Terikat (Dependent Variable)

Variabel ini sering disebut sebagai variabel respon, output, kriteria, konsekuen. Variabel terikat merupakan variabel yang dipengaruhi atau yang menjadi akibat karena adanya variabel bebas. Variabel 
terikat dalam penelitian ini adalah kepuasan pasien.

\section{B. Lokasi dan Waktu Penelitian}

1. Lokasi penelitian

Penelitian ini dilaksanakan di ruang IGD RSUD Bangkinang

2. Waktu Penelitian

Penelitian ini dilaksanakan pada tanggal 15-18 Mai 2018.

\section{Populasi dan Sampel}

\section{Populasi}

Populasi adalah keseluruhan subjek penelitian (Notoatmodjo, 2010). Populasi pada penelitian ini adalah pasien yang datang berobat ke IGD RSUD Bangkinang. Rata-rata pasien berobat 40 orang per hari.

\section{Sampel}

Sampel adalah sebagian objek yang diambil dari keseluruhan objek yang diteliti yang dianggap mewakili seluruh populasi (Hidayat, 2014). Yang menjadi sampel dalam penelitian ini adalah sebagian pasien yang datang berobat ke IGD RSUD Bangkinang. Sampel dapat dibagi atas:

a. Kriteria Sampel

1) Kriteria Inklusi:

a) Pasien atau keluarga pasien IGD yang bersedia menjadiresponden.

b) Pasien IGD dalam keadaan sadar dan mampuberkomunikasi.

c) Keluarga pasien IGD yang mengantar pasien dari awal dan menunggu hingga pasien selesaiditangani.

2) Kriteria eksklusi, yaitu:

a) Pasien atau keluarga yang tidak bersedia menjadi responden

b) Pasien tidak sadar selama penelitian dilakukan

b. Teknik Sampel

Adapun teknik pengambilan sampel yang digunakan pada penelitian ini menggunakan accidental sampling, dimana pengambilan sampel dilakukan dengan cara mengambil responden yang kebetulan ada pada saat dilakukan penelitian.

\section{Etika Penelitian}

Masalah etika penelitian keperawatan merupakan masalah yang sangat penting dalam penelitian, mengingat penelitian berhubungan langsung dengan manusia, maka segi etika peneltian harus di perhatikan. Maslah etika penelitian yang harus di perhatikan antara lain:

1. Lembar Persetujuan (Informed Consent )

Merupakan bentuk persetujuan antara peneliti dan responden penelitian dengan memberikan lembar persetujuan. Informed consent tersebut di berikan sebelum penelitian dilakukan. Tujuan informed consent adalah subjek mengerti maksud dan tujuan penelitian, mengetahui dampaknya. Jika calon responden bersedia, maka mereka akan mendatangi lembaran persetujuan tersebut. Jika responden tidak bersedia, maka peneliti harus menghormati hak pasien.

2. Tanpa Nama ( Anomity)

Untuk menjaga kerahasian responden maka peneliti tidak akan mencantumkan namanya pada lembaran pengumpulan data, cukup dengan memberikan nomor kode pada lembar pengumpulan data.

3. Kerahasiaan ( confidentiality)

Kerahasian hasil penelitian, baik informasi maupun masalah-masalah lainnya akan di jamin kerahasiaannya oleh peneliti.( Hidayat, 2014 ).

\section{E. Alat Pengumpulan Data}

Alat pengumpulan data yang digunakan dalam penelitian ini adalah kuesioner. Adapun bentuk pertanyaan yang berkaitan dengan kepuasan pasien berjumlah 20 pertanyaan dalam bentuk skala likert. Alat ukur yang digunakan menggunakan skala likert yang terdiri dari 4 kategori. Untuk pernyataan positif menggunakan kategori: Sangat Setuju (4), Setuju (3), Tidak Setuju (2) dan Sangat Tidak Setuju (1), dan untuk 
pernyataan negatif: Sangat Setuju (1), Setuju (2), Tidak Setuju (3) dan Sangat Tidak Setuju (4). Untuk pertanyaan respon time berbentuk lembar checklist

\section{F. Uji Validitas dan Reliabilitas}

Menurut Notoatmodjo (2012), kuesioner dapat digunakan sebagai alat ukur penelitian perlu uji validitas dan reliabilitas. Untuk itu kuesioner tersebut harus dilakukan uji coba "trial" dilapangan. Responden yang digunakan untuk uji coba sebaiknya yang memiliki ciri-ciri responden dari tempat dimana penelitian tersebut harus di laksanakan. Uji kuesioner dilakukan kepada 20 masyarakat usia produktif di Puskesmas Salo.

Untuk mengetahui validitas suatu instrument atau kuesioner dilakukan dengan cara melakukan korelasi antar skor masing-masing variabel (pertanyaan). Dikatakan valid bila skor variabel tersebut berkorelasi secara signifikan dengan skor totalnya. Teknik korelasi yang digunakan korelasi pearson product moment.

Untuk mengetahui reliabilitas yaitu sejauh manghasil pengukuran tetap konsisten bila dilakukan pengukuran 2 kali atau lebih terhadap gejala yang sama dan dengan alat ukur yang sama. Pengukuran reliabilitas dapat dilakukan dengan dua cara:

1) Repeated measure atau ukur ulag.

2) One shot atau diukur sekali saja.

Pada uji kuesioner yang dilakukan hanya akan dilakukan pengukuran sekali saja (one shot). Pengujian reliabilitas dimulai dengan uji validitas terlebih dahulu.Jika pertanyaan tidak valid, maka pertanyaan dibuang ,pertanyaan-pertanyaan yang sudah valid kemudian baru secara bersama-sama diukur reliabilitasnya. Untuk mengetahui reliabilitas dilakukan dengan cara melakukan uji Crombach Alpha keputusan uji adalah :

1) Bila Crombach Alpha $\geq 0,6$ artinya variabel reliabel.

2) Bila Crombach Alpha $<0,6$ artinya variabel tidak reliabel.
Kuesioner dalam penelitian ini telah baku diambil dari Penelitian Wahyudi (2016).

\section{G. Prosedur Pengumpulan Data}

Dalam melakukan penelitian ini, peneliti akan mengumpulkan data melalui prosedur sebagai berikut :

Dalam melakukan penelitian ini, peneliti akan mengumpulkan data melalui prosedur sebagai berikut :

1. Mengajukan surat permohonan izin kepada institusi Universitas Pahlawan Tuanku Tambusai Riau untuk mengadakan penelitian di RSUD Bangkinang

2. Setelah mendapat surat izin, peneliti memohon izin ke Direktur RSUD Bangkinang untuk melakukan penelitian di wilayah kerjanya.

3. Peneliti akan mmemberikan informasi secara lisan dan tulisan tentang manfaat dan etika penelitian serta menjamin kerahasiaan responden.

4. Jika calon responden bersedia menjadi responden, maka mereka harus menandatangani surat persetujuan menjadi responden yang diberikan peneliti.

5. Setelah responden menjawab semua pertanyaan, maka kuesioner dikumpulkan kembali untuk dikelompokkan.

\section{H. Teknik Pengolahan Data}

Dalam melakukan penelitian ini, data yang diperoleh akan diolah secara manual dengan komputerisasi, setelah data terkumpul, kemudian diolah dengan langkah-langkah sebagai berikut:

1. Pemeriksaan data (editing)

Editing adalah upaya untuk memeriksa kembali kebenaran data yang diperoleh atau dikumpulkan. Editing dapat dilakukan pada tahap pengumpulan data atau setelah data terkumpul. Dalam penelitian, peneliti memeriksa kembali kuesioner, apakah jawaban sudah lengkap, releven, dan konsisten. Hasil editing ditemukan 
kuesioner telah diisi lengkap oleh seluruh responden sehingga tidak perlu dilakukan pengumpulan data ulang.

2. Pemberian kode (coding)

Coding merupakan kegiatan membaca kide numerik (angka) terhadap data yang diiteliti atas beberapa kategori. Pemberian kode ini sangat penting bila pengolahan dan analisis data menggunakan koomputer. Biasanya dalam pemberian kode dibuat juga daftar kode dan artinya dalam satu buku (code book) untuk memudahkan kembali melihat lookasi dan arti suatu kode dari suatu variabel. Dalam penelitian ini untuk kemudahan dalam pengolahan data dan analisis data, maka peneliti memberi kode pada setiap pertanyaan dalam kuesioner.

3) Entri data

Data entri adalah kegiatan memasukkan data yang telah dikumpulkan kedalam master tabel atau database komputer, kemudian membuat distribusi frekuensi sederhana atau bisa juga dengan membuat tabel kontigensi.
Dalam penelitian, hasil coding menyatakan kelengkapan data dari responden maka dilakukan pemasukan data kedalam master tabel dan kemudian membuat distribusi frekuensinya.

4) Melakukan teknik analisa

Dalam melakukan analisis, khususnya terhadap data penelitian akan menggunakan ilmu statistik terapan yang disesuaikan dengan tujuan yang hendak dianalisis. Dalam penelitian ini, peneliti memasukkan data entri untuk uji chisquare dengan menggunakan system komputer (Hidayat, 2007).

\section{Defenisi Operasional}

Defenisi operasional adalah mendefenisikan variabel secara operasional berdasarkan karakteristik yang diamati. Sehingga memungkinkan penelliti untuk melakukan observasi atau pengukuran secara cermat terhadap suatu objek atau fenomena (Hidayat, 2007).

Defenisi operasional pada penelitian ini untuk lebih jelas dapat dilihat pada tabel 3.1 berikut:

Tabel 3.1 Defenisi Operasional

\begin{tabular}{|c|c|c|c|c|c|}
\hline No & Variable & $\begin{array}{c}\text { Defenisi } \\
\text { Operasional }\end{array}$ & Alat Ukur & $\begin{array}{l}\text { Skala } \\
\text { Ukur }\end{array}$ & Hasil Ukur \\
\hline & $\begin{array}{l}\text { Variabel } \\
\text { Independen }\end{array}$ & & & & \\
\hline 1 & Respon time & $\begin{array}{l}\text { Waktu tanggap } \\
\text { perawat dalam } \\
\text { menangani } \\
\text { pasien sesegera } \\
\text { mungkin }\end{array}$ & $\begin{array}{l}\text { Lembar } \\
\text { checklist }\end{array}$ & Ordinal & $\begin{array}{l}1=\text { Cepat }(<5 \text { menit }) \\
0=\underset{\text { Lambat }}{\text { menit })}(\geq 5\end{array}$ \\
\hline 2 & $\begin{array}{l}\text { Variabel } \\
\text { Dependen } \\
\text { Kepuasan } \\
\text { pasien }\end{array}$ & $\begin{array}{l}\text { Ungkapan } \\
\text { perasaan pasien } \\
\text { terhadap } \\
\text { pelayanan } \\
\text { diterima dengan } \\
\text { pelayanan yang } \\
\text { diharapkan }\end{array}$ & Kuesioner & Ordinal & $\begin{aligned} 1= & \begin{array}{l}\text { Puas, jika } \mathrm{x}> \\
\text { mean }(50,1)\end{array} \\
0= & \text { Tidak Puas, jika } \mathrm{x} \\
& \leq \text { mean }(50,1)\end{aligned}$ \\
\hline
\end{tabular}

\section{J. Analisis Data}

Data yang diperoleh dari hasil penelitian diolah dengan menggunakan komputerisasi, disajikan dalam bentuk distribusi frekuensi. Analisa data dilakukan dengan anlisa univariat dan analisa bivariat:

\section{1) Analisis Univariat}

Analisis univariat adalah analisa yang dilakukan terhadap tiap variabel dari hasil penelitian, analisis ini 
menghasilkan distribusi dan persentase dari tiap variabel ( Notoatmodjo, 2010). Analisis ini bermanfaat untuk memberi gambaran karakteristik subyek penelitian dengan menghitung distribusi frekuensi dan proporsi Perhitungan data dilakukan setelah data terkumpul, data tersebut klasifikasikan menurut variabel yang diteliti dan data diolah secara manual dengan menggunakan rumus sebagai berikut: Manual dengan menggunakan rumus sebagai berikut :

$$
\mathrm{P}=\frac{f}{N} x 100 \%
$$

Keterangan

$\mathrm{P}=$ Persentase

$\mathrm{F}=$ Frekuensi

$\mathrm{N}=$ Jumlah seluruh observasi

\section{2) Analisis Bivariat}

Analisa bivariat digunakan untuk meliihat hubungan antara variabel independen dengan variabel dependen. Analisa bivariat akan menggunakan uji Chi-Square $\left(\mathrm{X}^{2}\right)$ dengan menggunakan tingkat kepercayaan $95 \%$ dengan rumus

$$
x^{2} \sum \frac{(0-E) 2}{E}
$$

Keterangan :

0 : Nilai observasi

E : Nilai harapan.

Dasar pengambilan keputusan yaitu dengan membandingkan nilai $\mathrm{x}^{2}$ hitung dengan $\mathrm{x}^{2}$ tabel, sebagai berikut:

a. Jika $x^{2}$ hitung $\geq x^{2}$ tabel, maka Ha diterima dan Ho dit olak

b. Jika $x^{2}$ hitung $<x^{2}$ tabel, maka Ha tidak terbukti dan Ho gagal ditolak

Berdasarkan Probabilitas :

a. Jika Probabilitas (p) $\leq \alpha(0,05)$ Ha diterima dan Ho ditolak

b. Jika Probabilitas (p) $>\alpha(0,05) \mathrm{Ha}$ tidak terbukti dan Ho gagal ditolak

\section{BAB IV}

\section{HASIL PENELITIAN}

$\mathrm{Bab}$ ini menyajikan mengenai hasil penelitian tentang hubungan Response Time
Pelayanan Instalasi Gawat Darurat (IGD) Dengan Tingkat Kepuasan Pasien di RSUD Bangkinang tahun 2018. Penelitian ini dilakukan pada tanggal 15-18 Mai 2018 dengan jumlah responden 80 orang. Untuk lebih jelasnya dapat dilihat dalam bentuk analisis univariat dan bivariat:

\section{A. Analisa Univariat}

Analisa univariat dalam penelitian ini yaitu umur, pendidikan, pekerjaan, respon time dan kepuasan pasien. Hasil analisa dilihat pada tabel berikut"

\section{Umur}

Tabel 4.1 Distribusi Frekuensi Umur di Instalasi Gawat Darurat (IGD) RSUD Bangkinang Tahun 2018

\begin{tabular}{clll}
\hline No & \multicolumn{1}{c}{ Umur } & $\mathbf{N}$ & $\mathbf{( \% )}$ \\
\hline 1 & 26-35 tahun & 11 & 13,8 \\
2 & $36-45$ tahun & 27 & 33,7 \\
$\mathbf{3}$ & $\mathbf{4 6 - 5 5}$ tahun & $\mathbf{4 2}$ & $\mathbf{5 2 , 5}$ \\
\hline & Total & $\mathbf{8 0}$ & $\mathbf{1 0 0}$ \\
\hline
\end{tabular}

Sumber : Depkes, RI 2009

Dari tabel 4.1 dapat dilihat bahwa sebagian besar responden berumur 46-55 tahun yaitu sebanyak 42 orang $(52,5 \%)$.

2. Pendidikan

Tabel 4.2 Distribusi

Frekuensi

Pendidikan di Instalasi Gawat Darurat (IGD) RSUD Bangkinang Tahun 2018

\begin{tabular}{clcc}
\hline No & \multicolumn{1}{c}{ Pendidikan } & N & $(\boldsymbol{\%})$ \\
\hline $\mathbf{1}$ & Pendidikan Rendah & $\mathbf{4 9}$ & $\mathbf{6 1 , 2}$ \\
2 & Pendidikan Tinggi & 31 & 38,8 \\
\hline & Total & $\mathbf{8 0}$ & $\mathbf{1 0 0}$ \\
\hline
\end{tabular}

Sumber : Penyebaran kuesioner

Dari tabel 4.2 dapat dilihat bahwa sebagian besar responden berpendidikan rendah yaitu sebanyak 49 orang $(61,2$ $\%)$.

\section{Pekerjaan}

Tabel 4.2 Distribusi Frekuensi Pekerjaan di Instalasi Gawat Darurat (IGD) RSUD Bangkinang Tahun 2018

\begin{tabular}{clcc}
\hline No & Pekerjaan & $\mathbf{N}$ & $\mathbf{( \% )}$ \\
\hline $\mathbf{1}$ & Bekerja & $\mathbf{5 5}$ & $\mathbf{6 8 , 8}$ \\
2 & Tidak Bekerja & 25 & 31,2 \\
\hline & Total & $\mathbf{8 0}$ & $\mathbf{1 0 0}$
\end{tabular}

Sumber : Penyebaran kuesioner

Dari tabel 4.3 dapat dilihat bahwa sebagian besar responden bekerja yaitu sebanyak 55 orang $(68,8 \%)$. 


\section{Respon Time}

Tabel 4.1 Distribusi $\quad$ Frekuensi

Respon Time Perawat di Instalasi Gawat

Darurat RSUD Bangkinang Tahun 2018

\begin{tabular}{clcc}
\hline No & \multicolumn{1}{c}{ Respon time } & n & $\mathbf{( \% )}$ \\
\hline $\mathbf{1}$ & Lambat $(\geq \mathbf{5}$ menit $)$ & $\mathbf{5 1}$ & $\mathbf{6 3 , 8}$ \\
2 & Cepat $(<5$ menit $)$ & 29 & 36,2 \\
\hline \multicolumn{2}{l}{ Total } & $\mathbf{8 0}$ & $\mathbf{1 0 0}$ \\
\hline
\end{tabular}

Sumber: Penyebaran kuesioner

Dari tabel 4.4 dapat dilihat bahwa sebagian besar respon time perawat berada dalam kategori lambat yaitu sebanyak 51 orang $(63,8 \%)$.

\section{Kepuasan Pasien}

Tabel 4.2 Distribusi Frekuensi Kepuasan Pasien di RSUD Bangkinang Tahun 2018

\begin{tabular}{clcc}
\hline No & Kepuasan Pasien & $\mathbf{n}$ & $\mathbf{( \% )}$ \\
\hline $\mathbf{1}$ & Tidak Puas & $\mathbf{4 7}$ & $\mathbf{5 8 , 8}$ \\
2 & Puas & 33 & 41,3 \\
\hline & Total & $\mathbf{8 0}$ & $\mathbf{1 0 0}$ \\
\hline Sumber $:$ Penyeharan
\end{tabular}

Sumber: Penyebaran kuesioner

Dari tabel 4.3dapat dilihat bahwa sebagian besar pasien tidak puas terhadap pelayanan IGD yaitu sebanyak 47 orang $(58,8 \%)$.

\section{B. Analisa Bivariat}

Analisa bivariat ini menggambaran hubungan hubungan Response Time Pelayanan Instalasi Gawat Darurat (IGD) Dengan Tingkat Kepuasan Pasien di RSUD Bangkinang tahun 2018.Hasil analisis disajikan pada tabel berikut:

Tabel 4.3 Hubungan Respon Time dengan Kepuasan pasien

\begin{tabular}{|c|c|c|c|c|c|c|c|c|}
\hline \multirow{3}{*}{ Respon time } & \multicolumn{4}{|c|}{ Kepuasan Pasien } & \multirow{2}{*}{\multicolumn{2}{|c|}{ Total }} & \multirow{3}{*}{$\begin{array}{c}\mathrm{P} \\
\text { value }\end{array}$} & \multirow{3}{*}{ POR } \\
\hline & \multicolumn{2}{|c|}{ Tidak puas } & \multicolumn{2}{|c|}{ Puas } & & & & \\
\hline & $\mathrm{n}$ & $\%$ & $\mathrm{n}$ & $\%$ & $\mathrm{~N}$ & $\%$ & & \\
\hline Lambat & 37 & 78,7 & 14 & 42,4 & 51 & 100 & 0,002 & 5,0 \\
\hline Cepat & 10 & 21,3 & 19 & 57,6 & 29 & 100 & & \\
\hline Jumlah & 47 & 100 & 33 & 100 & 80 & 100 & & \\
\hline
\end{tabular}

Sumber : Hasil Uji Chi Square

Berdasarkan tabel 4.3 dapat diketahui bahwa dari 51 responden yang mengatakan respon time lambat, terdapat 14 pasien yang puas terhadap pelayanan IGD. Sedangkan dari 29 responden yang mengatakan respon time cepat, terdapat 10 pasien yang tidak puas terhadap pelayanan IGD. Berdasarkan uji statistik diperoleh nilai $\mathrm{p}=0,002(\mathrm{p}<0,05)$, dengan derajat kemaknaan $(\alpha=0,05)$. Ini berarti ada hubungan respon time dengan kepuasan pasien di IGD RSUD Bangkinang.

Dari hasil penelitian juga diketahui bahwa nilai $P O R=5$ hal ini berarti responden yang mengatakan respon time lambat berpeluang 5 kali untuk tidak puas terhadap pelayanan IGD.

\section{BAB V}

\section{PEMBAHASAN}

\section{A. Respon Time}

Dari hasil penelitian dapat dilihat bahwa sebagian besar respon time perawat berada dalam kategori lambat yaitu sebanyak 51 orang $(63,8 \%)$.

Menurut asumsi peneliti respon time harus dilakukan dalam waktu kurang dari 5 menit karena penanganan pasien gawat darurat yang cepat dapat menurunkan usaha penyelamatan pasien dan terjadinya perburukan kondisi pasien. Jika waktu tanggap lambat akan berdambak pada kondisi pasien seperti rusaknya organorgan dalam atau komplikasi, kecacatan bahkan kematian.

Penanganan gawat darurat di Instalasi Gawat Daurat (IGD) rumah sakit mempunyai filosofinya yaitu Time Saving it's Live Saving bisa diartikan waktu adalah nyawa atau seluruh tindakan yang dilakukan pada saat kondisi gawat darurat haruslah benar-benar efektif dan efisien. Hal ini mengingatkan pada kondisi tersebut pasien dapat kehilangan nyawa hanya dalam hitungan menit saja. Berhenti nafas 2-3 menit pada manusia dapat mengakibatkan kematian yang fatal (Sutawijaya, 2009).

Kebutuhkan akan respon time (waktu tanggap) yang tepat dan efisien sangat berperan penting dalam setiap pengambilan keputusan mulai sejak awal pasien datang hingga pasien dipindahkan dari Instalasi 
Gawat darurat. Response time (waktu tanggap) adalah kecepatan dalam penanganan pasien dihitung sejak pasien datang sampai dilakukan penanganan. respon time (waktu tanggap) pelayanan dapat dihitung dengan hitungan menit dan sangat dipengaruhi oleh berbagai hal, baik mengenai jumlah tenaga maupun komponen-komponen lain yang mendukung. (Haryatun dan Sudaryanto, 2008).

Hasil penelitian ini sesuai dengan penelitian Sukarni (2015) di IGD RSU PKU Muhammadiyah Gombong yang menyatakan bahwa sebagian besar perawat IGD melakukan respon time lambat pada pasien yaitu $56,4 \%$

\section{B. Kepuasan Pasien}

Dari hasil penelitian diketahui bahwa sebagian besar pasien tidak puas terhadap pelayanan IGD yaitu sebanyak 47 orang $(58,8 \%)$.

Menurut asumsi peneliti kepuasan pasien sangat diperlukan dalam pelayanan di IGD RSUD Bangkinang karena jika pasien puas terhadap elayanan maka memberikan dampak positif terhadap tenaga kerja perawat dan rumah sakit itu sendiri.

Menurut Ratri (2016), ketanggapan (responsivemess) pelayanan keperawatan merupakan salah satu pengertian sebagai kecepatan perawat dalam melaksanakan prosedur asuhan sehingga berdampak pada kecepatan perawat dalam mengatasi masalah kesehatan yang dialami oleh pasien. Tindakan pelayanan keperawatan yang cepat dang tanggap sangat diperlukan untuk kualitas kepuasan yang dirasakan oleh pasien. Dalam pencapaian kepuasan pasien yang maksimal pelaksanaan pelayanan keperawatan harus sesuai kode etik yang ada pada masing-masing rumah sakit dan perlunya peningkatan kualitas pelayanan didalamnya.

Kepuasan yang dirasakan pasien ini menunjukan bahwa perawat di dapat memenuhi harapan-harapan pasien akan pelayanan yang prima dan berkualitas baik dari sisi kejelasan informasi, pelayanan yang tepat waktu, kesediaan perawat dalam mendengarkan keluhan atau permasalahan pasien dan kesediaan membantu mengatasi permasalahan tersebut. Kepuasan pasien akan pelayanan keperawatan merupakan hal mutlak yang harus dipenuhi oleh perawat sebab salah satu indikator jaminan mutu suatu rumah sakit adalah pernyataan puas dari penerima pelayanan atau pasien (Sulastri, 2015).

Hasil penelitian ini sesuai dengan penelitian Erina (2015) di RSKIA Muhammadiyah Bantul yang menyatakan bahwa sebagain besar responden tidak puas terhadap pelayanan di IGD RSKIA Muhammadiyah Bantul yaitu 57,8\%

C. Hubungan Response Time Pelayanan Instalasi Gawat Darurat (IGD) Dengan Tingkat Kepuasan Pasien di RSUD Bangkinang tahun 2018

Berdasarkan hasil penelitian dapat diketahui bahwa terdapat hubungan Response Time Pelayanan Instalasi Gawat Darurat (IGD) Dengan Tingkat Kepuasan Pasien di RSUD Bangkinang tahun 2018 dengan $p$ value 0,002 .

Menurut peneliti, response time (waktu tanggap) perawat dalam penanganan kegawatdaruratan yang cepat dan tepat akan meningkatkan tingkat kepuasan kepada pasien dan keluarga pasien. Terlihat dari hasil penelitian bahwa semakin cepat response time perawat terhadap pasien maka tingkat kepuasaan akan semakin meningkat dan sebaliknya semakin lambat respon yang diberikan oleh perawat maka akan megurangi tingkat kepuasaan pasien atau kelarga pasien terhadap kinerja perawat. Perawat harus mampu memberikan informasi kepada pasien agar pasien dan keluarga pasien mengetahui berapa menit standar penanganan yang harus dilakukan. Seorang perawat yang memberikan informasi tentang waktu tanggap kegawatdaruratan kepada pasien atau keluarga pasien, akan memberikan 
dampak yang positif, salah satunya adalah kepuasan yang meningkat.

Sedangkan pasien yang merasa tidak puas, dapat disebabkan oleh beberapa faktor diantaranya karakteristik pasien yang datang ke IGD, terutama saat sore dan malam hari, tidak semua merupakan kasus true emergency, yang membutuhkan penanganan segera, sehingga kecepatan bukan merupakan hal utama yang diinginkan, namun keramahan dan kemampuan profesional petugas di IGD dalam memberikan pelayanan dan kesempatan untuk berinteraksi/berdiskusi menjadi faktor yang diharapkan pasien. Faktor lain yang tidak bisa dikesampingkan adalah budaya masyarakat. Mayoritas pasien yang datang di RSUD Bangkinang yang lebih mengutamakan keramahan daripada kecepatan, terlebih apabila kecepatan yang ditunjukkan dalam melayani memberikan kesan tergesa-gesa, tidak teliti dan kurang peduli terhadap keluhan pasien.

Salah satu indikator keberhasilan penanggulangan medik penderita gawat darurat adalah kecepatan memberikan pertolongan yang memadai kepada penderita gawat darurat baik pada keadaan rutin sehari-hari atau sewaktu bencana. Keberhasilan waktu tanggap atau response time sangat tergantung kepada kecepatan yang tersedia serta kualitas pemberian pertolongan untuk menyelamatkan nyawa atau mencegah cacat sejak di tempat kejadian, dalam perjalanan hingga pertolongan rumah sakit. pertama darurat melibatkan dua komponen utama yaitu pertolongan fase pra rumah sakit dan fase rumah sakit. Kedua komponen tersebut sama pentingnya dalam upaya pertolongan gawat darurat. (Muwardi, 2015)

Response time perawat adalah kecepatan atau waktu tanggap pelayanan yang cepat (reponsif), dihitung sejak pasien datang sampai dilakukan penanganan. Waktu tanggap pelayanan merupakan gabungan dari waktu tanggap saat pasien tiba didepan pintu rumah sakit sampai mendapat tanggapan atau respon dari petugas instalansi gawat darurat yang waktu pelayanan yaitu waktu yang diperlukan pasien sampai selesai (Karika, 2013).

Response time sangat penting dalam menangani pasien gawat darurat khususnya pasien dengan prioritas 1 , response time yang cepat dapat menimbulkan rasa puas terhadap pelayanan yang dirasakan oleh keluarga pasien ditunjang juga dengan sikap peduli atau emphaty dan kemarahan juga komunikasi yang baik antara keluarga pasien dengan petugas kesehatan khusunya perawat (Kartika, 2013).

Upaya memberikan pelayanan agar bisa memberikan kepuasan pasien khususnya pelayanan gawat darurat dapat dinilai dari kemampuan perawat dalam hal responsiveness (cepat tanggap), reliability (pelayanan tepat waktu), assurance (sikap dalam memberikan pelayanan), emphaty (kepedulian dan perhatian dalam memberikan pelayanan) dan tangible (mutu jasa pelayanan) dari perawat kepada pasien (Muninjaya 2011).

Waktu tanggap gawat darurat merupakan gabungan dari waktu tanggap saat pasien tiba di depan pintu rumah sakit sampai mendapat respon dari petugas Instalasi Gawat Darurat (response time) dengan waktu pelayanan yang diperlukan sampai selesai proses penanganan gawat darurat (Haryatun, 2008).

Menurut Nusantara (2012), faktor-faktor yang mempengaruhi kepuasan pasien, antara lain faktor psikologis, faktor demografi dan faktor geografis. Faktor psikologis meliputi manfaat yang diharapkan dan persepsi atau pemahaman terhadap produk atau pelayanan yang diberikan yaitu pelayanan petugas rumah sakit terhadap pasien.

Hal ini sesuai dengan teori dari American College of Emergency Physician (2008) yang menyatakan bahwa pada IGD yang mengalami permasalahan banyaknya jumlah pasien yang ingin mendapatkan pelayanan, maka menempatkan seorang dokter di wilayah triase dapat mempercepat 
proses pemulangan pasien atau discharge untuk pasien minor dan membantu memulai penanganan bagi pasien yang kondisinya lebih sakit.

Petugas IGD hendaknya mengetahui bahwa kualitas pelayanan perawat baik itu responsiveness, empathy, reliability maupun assurance dapat membuat kepuasan pelanggan di IGD terjaga pada tingkat tinggi. Manajemen rumah sakit hendaknya bisa memilah pasien true emergency dan false emergency dengan adanya layanan klinik 24 jam, sehingga tingkat signifikasi response time dengan kepuasan pelanggan akan lebih jelas (Rusdianto, 2012)

Perawat harus memiliki kemampuan untuk penanganan gawat darurat dengan baik dan menciptakan rasa puas bagi pasien. Kepuasan dimulai dari penerimaan pasien dari pertama kali datang sampai mendapatkan pelayanan, pelayanan dibentuk berdasarkan 5 prinsip service quality yaitu kecepatan, ketepatan, keamanan, keramahan dan kenyamanan layanan, sehingga dari peran perawat yang advokat kepada psien dan penanganan yang cepat, tepat,nyaman serta keramahan perawat kepada pasien akan menimbulkan tingkat kepuasan yang meningkat dan kinerja yang baik

Hasil penelitian ini sesuai dengan penelitian yang dilakukan oleh Widodo (2016) yaitu ada hubungan response time perawat dalam memberikan pelayanan dengan kepuasan pelanggan di IGD RS. Panti Waluyo Surakarta dengan $\mathrm{p}$ value 0,042 dan koefisien korelasi sebesar 0,209

\section{DAFTAR PUSTAKA}

Basuki. (2015). Penanggulangan penderita gawat darurat anestesiologi \& reanimasi. Surabaya: FK. Unair.

Depkes RI. (2012). Pedoman Manajemen Sumber Daya Manusia (SDM) Kesehatan Dalam Penanggulangan Bencana.Kementrian Kesehatan : Jakarta
Dinda. (2016). Agenda Gawat Darurat (Critical Care) Jilid 3. Bandung: PT Alumin.

Fatimah. (2017). Hubungan Antara Presepsi Pasien Terhadap Dimensi Mutu Pelayanan keperawatan Dengan Kepuasan Pasien Diruangan Rawat inap Rumah Sakit Umum PKU Muhammadiyah Temanggung. Diakses tanggal 17 April 2018

Faiz. (2016). Kepuasan pasien instalasi gawat darurat terhadap pelayanan perawat $D i$ Rsud Tugurejo Semarang. Thesis, Program Studi Magister Promosi Kesehatan Kajian Sumberdaya Manusia

Haryatun. (2013). Perbedaan Waktu Tanggap Tindakan Keperawatan Pasien Cedera Kepala Kategori I-V Di Instalasi Gawat Darurat RSUD Dr. Moewardi. Jurnal Berita Ilmu Keperawatan. Diakses tanggal 14 April 2018

Hidayat. (2014). Metode penelitian keperawatan dan teknis analisis data. Jakarta : Salemba Medika.

Lestari. (2010). Faktor-Faktor yang Berhubungan dengan Ketepatan Waktu Tanggap Penanganan Kasus pada Respon Time I di Instalasi Gawat Darurat Bedah dan Non Bedah RSUP dr. Wahidin Sudirohusodo. Diakses tanggal 17 April 2018

Muslihan. (2010). Keperawatan Gawat Darurat. Nuha Medika : Yogyakarta.

Notoatmodjo. (2014). Metodologi Penelitian Kesehatan. Jakarta: Rineka Cipta hal. 37-8.

Pratiwi. (2011). Hubungan Beban Kerja dengan Waktu Tanggap Perawat Gawat Darurat Menurut Persepsi Pasien di Instalasi Gawat Darurat RSU Pandan Arang Boyolali. Diakses tanggal 12 April 2018

Risman. (2015). Hubungan Kualitas Pelayanan Kesehatan dan Kepuasan Pasien Rawat Inap di Badan Pelayanan Kesehatan Rumah Sakit Umum Daerah Kab. Magelang. Jurnal Kesehatan. 
Yogyakarta: Departemen Ilmu

Kesehatan Masyarakat. Universitas

Islam Indonesia.

Sudiharto. (2010). Basic Trauma Cardiac Life

Support. Jakarta: Sagung Seto

Suhartati. (2011). Standar Pelayanan

Keperawatan Gawat Darurat di Rumah

Sakit. Jakarta: Kementrian Kesehatan.

Sudaryanto. (2014). Perbedaan Waktu

Tanggap Tindakan Keperawatan Pasien

Cidera Kepala Kategori I-V Di Instalasi

Gawar Darurat RSUD De. Moewardi.

Jurnal Berita Ilmu keperawatan.

Jakarta.EGC

Samsinar. (2014). Hubungan Faktor-Faktor

Eksternal Dengan Response Time

Perawat Dalam Penanganan Pasien

Gawat Darurat di IGD RSUP Prof. Dr.

R. D Kandau Manado. Diakses tanggal 16 Mei 2018

Widyawati. (2016). Memahami Penggunaan

Ilmu Ekonomi Dalam Manajemen

Rumah Sakit. Yogyakarta: Gadjah Mada University Press.

Yulianingsih. (2011). Evaluasi Penerapan

Code Green dalam Mempercepat

Response Time pada Kasus Gawat Janin di IGD RSUP Sanglah Denpasar

Bustami. (2011). Manajemen Unit Gawat

Darurat pada Penanganan Kasus

Kegawatdaruratan

Haryatun. (2013). Pengetahuan Perawat

Tentang Response Time Dalam

Penanganan Penanganan Gawat

Darurat Di Ruang Triage Karanganyar.

Skripsi. Soekanto S, Herkutanto. 